\title{
PENGGUNAAN METODE DEMONTRASI DAN MEDIA AUDIO VISUAL DALAM MENINGKATKAN HASIL BELAJAR PESERTA DIDIK MATA PELAJARAN IPS
}

\author{
Wahyu Bagja Sulfemi ${ }^{1}$, Nurhasanah ${ }^{2}$ \\ ${ }^{1}$ STKIP Muhammadiyah Bogor \\ Komplek Perguruan Muhammadiyah Jln. Raya Leuwiliang No.106, Bogor. \\ wahyubagja@gmail.com \\ ${ }^{2}$ Guru SD Negeri Pitara 2 \\ JL. Pitara Raya No 165 \\ nurhasanahyess5@gmail.com
}

\begin{abstract}
ABSTRAK
Penelitian ini bertujuan untuk meningkatkan hasil belajar Ilmu Pengetahuan Sosial peserta didik dengan menggunakan metode demontrasi dan media audio visual. Penelitian ini dilakukan Di Sekolah Dasar Negeri Pitara 2 Kecamatan Pancoranmas Kota Depok yang jumlah 41 peserta didik, terdiri dari 27 laki-laki dan 14 orang perempuan. Proses Penelitian ini terdiri dari Prasiklus, Siklus 1 dan Siklus 2. Pada saat prasiklus diketahui nilai rata-rata peserta didik sebesar 65,5 nilai masih dibawah KKM 75,00. sehingga perlu diadakan perbaikan kembali. Maka pada siklus I menunjukkan hasil belajar siswa 69,3\% dan meningkat menjadi 87,3\% pada siklus II. Pada siklus ini telah dicapai ketuntasan belajar karena nilai rata-rata peserta didik telah mencapai diatas nilai KKM. Dari hasil penelitian ini maka diketahui bahwa penggunan metode demontrasi melaui media gambar pada audio visual dapat meningkatkan hasil belajar peserta.
\end{abstract}

Kata kunci : Hasil Belajar, Metode Demonstrasi, Audio-Visual.

\section{ABSTRACT}

This study aims to improve learning outcomes of Social Sciences learners by using methods of demonstration and audio visual media. This research was conducted at Pitara 2 State Elementary School in Pancoranmas Subdistrict of Depok City with 41 students consisting of 27 men and 14 women. The research process consists of Prasiklus, Cycle 1 and Cycle 2. At Praslus time it is known that the average value of the learners is 65,5 value is still below KKM 75,00. so it needs to be repaired again. So in the first cycle showed student learning outcomes $69.3 \%$ and increased to $87.3 \%$ in cycle II. In this cycle has been achieved mastery learning because the average value of learners has reached above the value of minimal coverage criteria. From the results of this study it is known that the use of demographic methods through the media images in audio visuals can improve participants' learning outcomes. Keywords: Learning Outcomes, Demonstration Method, Audio-Visual.

\section{PENDAHULUAN}

Ilmu Pengetahuan Sosial atau disingkat IPS merupakan bidang studi meliputi gejala-gejala dan masalah kehidupan manusia di masyarakat. Mata Pelajaran IPS memiliki tujuan untuk membentuk warga negara yang berkemampuan sosial dan memiliki keyakinan akan kehidupannya sendiri di tengah-tengah kekuatan fisik dan sosial, yang pada gilirannya akan menjadi warga negara yang baik dan bertanggung jawab (Sardjiyo, 2014:1.26). Untuk mencapai tujuan pembelajaran ini peserta didik harus memahami materi pembelajaran dan mendapatkan nilai sesuai Kriteria Ketuntasan Minimal atau KKM (Sulfemi, 2016: 52-70).

KKM bisa tercapai karena adanya peran serta peserta didik sebagai subjek belajar pada proses pembelajaran dan guru sebagai fasilitator yang akan memberikan kemudahan dalam proses pembelajaran. Akan tetapi, dalam hal ini pelajaran IPS masih sukar untuk dikuasai oleh peserta didik kelas IV SD Negeri Pitara 2 Kota
Depok, sehingga pada saat proses pembelajaran berlangsung peserta didik tidak aktif dan tidak bisa menjawab beberapa pertanyaan yang diberikan secara lisan pada pelajaran IPS, selain itu hasil evaluasi peserta didik belum mencapai KKM yang sudah ditetapkan yaitu 70 .

Berdasarkan hasil evaluasi pada prasiklus bahwa peserta didik di SD Negeri Pitara 2 permasalahan muncul adalah hasil nilai mata pelajaran IPS kelas IV ternyata di peroleh nilai rata-rata kelas tidak mencapai atau kurang dari KKM. Peserta didik yang berjumlah 41 hanya 22 peserta didik yang mencapai atau lebih dari KKM, sedangkan 19 peserta didik lainnya memperoleh nilai di bawah atau kurang dari KKM. Hasil evaluasi diperoleh nilai rata-rata kelas adalah 63,00 .

Untuk itu upaya peneliti dalam memperbaiki dan meningkatkan hasil yang lebih baik, peneliti melakukan Penelitian Tindakan Kelas (PTK). Penelitian ini dilakukan dalam beberapa siklus, setiap siklus diharapkan mendapat perubahan dan 
peningkatan ke arah yang lebih baik. Dengan bantuan teman sejawat, maka diadakan refleksi sehingga muncul permasalahan yang dianggap serius dalam proses pembelajaran. Hal ini disebakan guru merupakan faktor sentral di dalam sistem pembelajaran terutama di sekolah. Profesionalitas guru perlu dikembangkan secara terus menerus dan proporsional menurut jabatan fungsional guru. (Salim, 2018: 46-54). Dalam hal ini peneliti harus mencari metode yang sesuai dengan materi, kemampuan peserta didik, dan memberikan pengalaman nyata dengan melibatkan peserta didik dalam pengalaman belajar yang menyenangkan untuk itu coba digunakan metode demonstrasi dengan batuan audio visual.

Sagala, (2011:210) menyampaikan bahwa metode demonstrasi adalah metode yang digunakan untuk memperlihatkan suatu proses atau cara kerja suatu benda yang berkenaan dengan bahan bahan pelajaran. Penggunaan metode demonstrasi bermanfaat bagi peserta didik agar memiliki kesempatan untuk mengembangkan kemampuan untuk mengamati segala benda yang sedang terlibat dalam proses pembelajaran serta dapat mengambil kesimpulan-kesimpulan yang diharapkan.

Metode demonstrasi semata-mata digunakan hanya untuk: 1) Mengkongkritkan suatu konsep atau prosedur yang abstrak, 2) Mengajarkan bagaimana berbuat atau menggunakan prosedur secara tepat, 3) Meyakinkan bahwa alat dan prosedur tersebut bisa digunakan, 4) Membangkitkan minat menggunakan alat prosedur (Anitah, 2014:5.25).

Karakteristik metode demonstrasi pada dasarnya untuk menyampaikan pembelajaran pada peserta didik dalam penguasaan proses objek tertentu. Pelaksanaan metode demonstrasi selain guru yang menjadi model, tetapi dapat menghadirkan nara sumber untuk mendemonstrasikan objek materi pelajaran. Tujuannya agar pembelajaran agar materi dapat dipahami oleh peserta didik (Majid Abdul, 2014: 155).
Saparati (2012:5.5), menyampaikan media audio visual adalah media yang mempunyai unsur suara dan unsur gambar. Media ini mempunyai kemampuan yang lebih baik, karena meliputi kedua jenis media auditif atau mendengar dan visual atau melihat. Media audio visual adalah alat bantu audio visual yang berupa alat yang dipergunakan dalam pembelajarn untuk membantu tulisan dan kata yang diucapkan dalam mentransfer pengetahuan, sikap, dan ide. Media audio visual merupakan media perantara atau penggunaan materi dan penyerapannya melalui pandangan dan pendengaran sehingga membangun kondisi yang dapat membuat peserta didik mampu memperoleh pengetahuan, keterampilan, atau sikap.

Berdasarkan latar belakang masalah dapat dirumuskan pokok rumusan masalah adalah bagaimana peranan metode demonstrasi dan media audio visual dalam meningkatkan hasil belajar IPS kelas IV SD Negeri Pitara 2 kota depok?. Masalah ini dapat diperinci, sebagai berikut: 1) Bagaimana peranan metode demonstrasi dalam meningkatkan hasil belajar IPS Kelas IV SD Negeri Pitara 2 Kota?, dan 2) Bagaimana peranan media audio visual dalam meningkatkan hasil belajar IPS Kelas IV SD Negeri Pitara 2 Kota Depok?.

Tujuan penelitian ini adalah untuk mengetahui peranan demonstrasi dan media audio visual dalam meningkatkan hasil belajar IPS kelas IV SD Negeri Pitara 2 Kota Depok. Tujuan penelitian tersebut dapat dijabarkan sebagai berikut: Pertama, bagi peserta didik memilki tujuan sebagai berikut: a) Meningkatkan prestasi belajar peserta didik kelas IV SD Negeri Pitara 2 kota Depok pada mata pelajaran IPS melalui demonstrasi dan media audio visual, b) Meningkatkan motivasi belajar peserta didik kelas IV SD Negeri Pitara 2 kota depok pada mata pelajaran IPS melalui demonstrasi dan media audio visual, dan c) Memahami materi dan menarik minat peserta kelas IV SD Negeri Pitara 2 kota depok pada mata pelajaran IPS melalui demonstrasi dan media audio visual

Kedua, bagi guru PTK ini memiliki tujuan sebagai berikut: 1) Sebagai acuan dalam perbaikan pembelajaran pada mata 
kuliah Pemantapan Kemampuan Profesional (PKP), dan 2) Meningkatkan kemampuan guru dalam menggunakan berbagai metode yang bervariasi pada kegiatan pembelajaran untuk mata pelajaran IPS.

\section{METODE}

Penelitian PTK ini akan dilaksanakan di Kelas 4 SD Negeri Pitara 2 Kecamatan Pancoranmas Kota Depok. Mata Pelajaran IPS dengan jumlah peserta didik 41 peserta didik yang terdiri dari 27 laki-laki dan 14 orang perempuan. Penelitian ini dilaksanakan mulai tanggal 9 Agustus 2017 diawali dengan prasiklus yang menjadi sumber masalah yang ditemukan, kemudian dilanjutkan perbaikan pembelajaran siklus I serta perbaikan pembelajaran siklus II yang dilaksanakan pada tanggal 23 Agustus 2017.

Teknik pengumpulan data yang digunakan dalam penelitian ini antara lain: 1) Observasi, digunakan untuk mengamati kegiatan selama proses pembelajaran serta peransertapesertadidikdalam

pembelajaran. Pengamatan dilakukan selama proses penelitian dari prasiklus, siklus I, dan siklus II, 2) Tes, digunakan untuk mengetahui keberhasilan peserta didik. Tes yang diberikan kepada peserta didik berupa petanyaan lisan dan tertulis (LKS).

Data diperoleh berupa data kuantitatif dan data kualitatif. Data kuantitatif dalam Penelitian Tindakan Kelas ini berupa angka-angka yang sederhana, contohnya: nilai evaluasi, persentasi, ataupun distribusi frekuensi. Data kualitatif yang diperoleh dari hasil belajar yang dilakukan secara deskriptif. Analisis tersebut dilakukan dengan menghitung nilai hasil evaluasi peserta didik pada prasiklus, siklus I, dan siklus II, dengan mengklasifikasikan nilai yang tuntas maupun tidak tuntas dalam

memperlancar kegiatan penelitian perbaikan pembelajaran IPS, selain itu juga meminta bantuan teman sejawat dalam hal pengamatan pada kegiatan pembelajaran yang dilakukan oleh penulis (Wardani, 2014: 1.5).

\section{HASIL DAN PEMBAHASAN}

Penelitian Tindakan Kelas (PTK) yang telah dilaksanakan penulis dalam 3 (Tiga) kali pertemuan yaitu pertemuan awal pra siklus, pertemuan siklus 1, dan pertemuan siklus 2. Lama pembelajaran dari setiap siklus adalah 2 X 35 menit (2 jam pelajaran). Selama kegiatan perbaikan pembelajaran berkolaborasi dengan teman sejawat.

Pada prasiklus dengan menggunakan metode pembelajaran ceramah dan menggunakan media papan tulis diperoleh jumlah nilai keseluruhan sebesar 2685, ratarata kelas hanya sebesar 65,5 nilai tertinggi sebesar 80 dan nilai terendah 40 dengan peserta didik yang tuntas dalam belajar 22 orang dari 41 peserta didik atau sebesar $53,65 \%$ yang belum mencapai KKM sebanyak $46,34 \%$ atau 19 orang dari 41 peserta didik. Hasil pengamatan peserta didik yang dapat menjawab pertanyaan guru baru mencapai 46,34 \% dan 53,65\% masih belum dapat menjawab.

Berdasarkan pengamatan dan observasi saat guru mengajar,yang menjadi permasalah dalam pembelajaran tersebut adalah: 1) Peserta didik kurang tertarik dalam megikuti kegiatan pembelajaran, 2) Nilai rata-rata di bawah KKM yang ditetapkan, 3) Kegiatan pembelajaran membosankan bagi peserta didik. 4) Keterlibatan atau partisipasi peserta didik masih rendah, dan 5) Guru terlalu dominan dalam kegiatan pembelajaran. Rendahnya nilai ini sesuai dengan penelitian yang dilakukan oleh Darmawan, (2017: 1-13).

Hasil nilai yang tidak mencapai KKM tersebut maka dilakukan perbaikan pembelajaran selanjutnya yaitu dengan: 1) lebih memotivasi peserta didik dengan kegiatan pembelajaran yang menarik dan menyenangkan, 2) bertindak sebagai fasilitator dan memberikan kesempatan kepada peserta didik untuk aktif dalam pembelajaran, 3) harus pintar memilih media atau alat peraga yang tepat dan dapat menarik perhatian peserta didik, 4) harus lebih cermat memilih metode yang tepat sesuai dengan materi yang disampaikan, dan 5) Guru harus dapat menggunakan waktu sebaik mungkin dalam kegiatan pembelajaran. Hal ini sesuai yang disampaikan oleh Simbolon, dan Sahyar 
(2015; 299-315) bahwa model konvensional sulit menaikan nilai peserta didik.

Dalam mengatasi permasalahan tersebut, peneliti melakukan perbaikan pengajaran dengan menambahkan metode pembelajaran yang sesuai dengan kompetensi dasar mendeskripsikan hubungan antara struktur kerangka tubuh manusia dengan fungsinya dan penelitian dilanjutkan kesiklus berikutnya yaitu siklus I yaitu dengan metode pembelajaran demontrasi. Pada pembelajaran Siklus 1 diperoleh jumlah nilai seluruhnya 2840 dengan rincian nilai tertinggi 90 dan nilai terendah 40. Dari hasil rata-rata kelas 69,3 peserta didik yang tuntas sebanyak 24 peserta didik atau sebesar 58,53\% dan yang belum mencapai ketuntasan belajar sebanyak $41,46 \%$ atau 17 peserta didik. Sedangkan hasil pengamatan diperoleh 29 orang menjawab benar dengan presentase $70,73 \%$ dan 12 peserta didik yang menjawab salah atau $29,26 \%$.

Hasil evaluasi pelaksanaan pembelajaran Siklus I menunjukan peroleh yang kurang maksimal untuk itu maka

dilakukan perbaikan pembelajaran berikutnya dengan melakukan tindakan dengan memotivasi peserta didik dengan kegiatan pembelajaran yang menarik dan menyenangkan dan memilih media atau alat peraga yang tepat dan dapat menarik perhatian peserta didik. Dalam mengatasi permasalahan tersebut, peneliti melakukan perbaikan pengajaran dengan menambahkan metode pembelajaran yang sesuai dengan kompetensi dasar mendeskripsikan hubungan antara struktur kerangka tubuh manusia dengan fungsinya dan penelitian dilanjutkan kesiklus berikutnya yaitu siklus 2 .

Pada pembelajaran siklus II, dengan menambahkan media pembelajarannya yaitu media audio visual diperoleh jumlah nilai seluruhnya 3170 dengan rincian nilai tertinggi 90 dan nilai terendah 60, hasil rata-rata kelas 87,3. Peserta didik yang tuntas dalam belajar sebanyak 38 peserta didik atau sebesar $92,68 \%$ dan yang belum mencapai tuntas belajar sebanyak $7,31 \%$ atau 3 peserta didik. Sedangkan hasil pengamatan diperoleh 35 orang menjawab benar dengan presentase $82,3 \%$ dan 6 peserta didik yang menjawab salah atau $14,63 \%$.

Peneliti melakukan pengamatan terhadap aktivitas peserta didik dalam mengikuti perbaikan pembelajaran. Penggunaan metode demontrasi dan pemberian tugas dengan bantuan media audio visual, ada perubahan yang signifikan dalam proses maupun hasil belajar peserta didik. Setelah diberi evaluasi, dari siklus I dengan nilai rata-rata 67,3171 dengan peserta didik yang dapat menjawab 58,5366 $\%$ meningkat menjadi nili rata-rata 75,3658 dengan peserta didik yang bisa menjawab $92,682 \%$ Selain peningkatan pada nilai rata-ratanya, proses belajar semakin kondusif, semua terlihat mengamati tayangan yang ditampilkan menggunakan audio visual. Setelah selesai pembelajaran, peserta didik dapat menyelesaikan evaluasi dengan lebih mudah. Berikut hasil perbandingan ini yang diperoleh dari tiaptiap siklus mengalami perbedaan.

Tabel 1. Prosentase Keberhasilan Hasil Belajar Peserta Didik

\begin{tabular}{|c|c|c|c|c|c|c|c|}
\hline \multirow{2}{*}{ No } & \multirow{2}{*}{ Kriteria } & \multicolumn{2}{|c|}{ Prasiklus } & \multicolumn{2}{c|}{ Siklus 1 } & \multicolumn{2}{c|}{ Siklus 2 } \\
\cline { 3 - 8 } & & Jumlah & $\%$ & Jumlah & $\%$ & Jumlah & $\%$ \\
\hline 1. & Tuntas & 22 & $53,65 \%$ & 24 & $58,53 \%$ & 38 & $92,68 \%$ \\
\hline 2. & Belum Tuntas & 19 & $46,34 \%$ & 17 & $41,46 \%$ & 3 & $7,31 \%$ \\
\hline 3. & Nilai Rata - rata & \multicolumn{2}{|c|}{65,5} & \multicolumn{3}{c|}{69,3} & \multicolumn{2}{c|}{82,3} \\
\hline
\end{tabular}

Tabel 2. Data Pengamatan Hasil Belajar Prasiklus, Siklus I dan Siklus II

\begin{tabular}{|c|c|c|c|c|c|}
\hline \multirow{2}{*}{ Keberhasilan } & \multicolumn{2}{|c|}{ Prasiklus } & \multicolumn{2}{c|}{ Siklus I } & \multicolumn{2}{c|}{ Siklus II } \\
\cline { 2 - 6 } & Jumlah & $\%$ & Jumlah & Jumlah & $\%$ \\
\hline
\end{tabular}


Wahyu B.S, Nurhasanah. Jurnal Pendas Mahakam. Vol 3 (2). 151-158. Agustus 2018

\begin{tabular}{|c|c|c|c|c|c|c|}
\hline Menjawab Benar & 19 & $46,34 \%$ & 29 & $70,73 \%$ & 35 & $85,36 \%$ \\
\hline Menjawab Salah & 22 & $53,65 \%$ & 12 & $29,26 \%$ & 6 & $14,63 \%$ \\
\hline jumlah & 41 & $100 \%$ & 41 & $100 \%$ & 41 & $100 \%$ \\
\hline
\end{tabular}

Berdasar pada tabel 1 dan 2 dapat dijelaskan bahwa pada prasiklus nilai ratarata kelas yang diperoleh peserta didik adalah 65,5 Siklus 1 sebesar 69,3 dan pada siklus 2 mengalami kenaikan sebesar 87,3. Sedangkan ketuntasan belajar dari pra siklus yang hanya 19 orang peserta didik atau 46,34\% naik menjadi 29 orang peserta didik atau $70,73 \%$ pada siklus 1, pada siklus 2 kenaikan menjadi 35 orang peserta didik atau $85,36 \%$

Hasil pengamatan pada pembelajaran pada prasiklus persentase peserta didik yang dapat menjawab pertanyaan guru 46,34 \% lebih kecil dibandingkan dengan yang tidak dapat menjawab 53,65\%. Pada siklus I dan II persentase yang dapat menjawab terus meningkat, yaitu sebesar $70,73 \%$ di siklus I dan $85,36 \%$ di siklus II. Hal ini menunjukan pemahaman peserta didik terhadap pembelajaran meningkat pula. Hasil ini ditampilkan dalam grafik dibawah ini

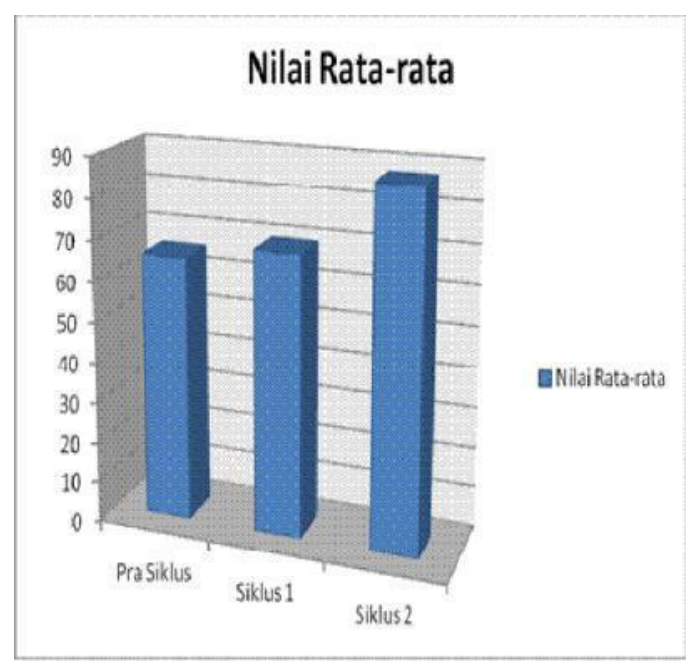

Grafik 1. Perolehan Nilai Rata-Rata Hasil Belajar

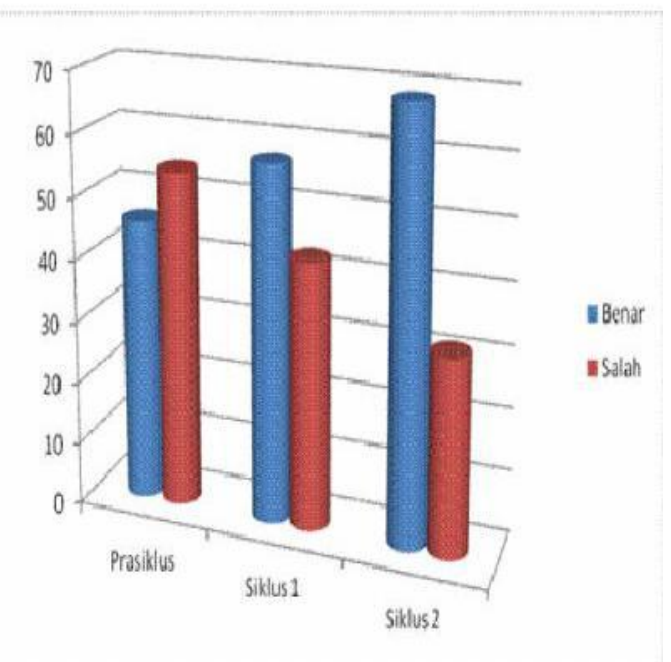

\section{Grafik 2. Pengamatan Hasil Belajar Prasiklus, Siklus I dan Siklus II}

Hasil Penelitian Tindakan Kelas ini sejalan dengan penelitian yang disampaikan oleh Erlinda (2017: 585-593), Anitah (2014:5.25) dan Irman, (2017: 1-16) menyampaikan bahwa manfaat psikologis metode demonstrasi adalah sebagai berikut:

1) Perhatian peserta didik akan berpusat pada materi, 2) Proses pembelajar peserta didik terarah pada materi yang sedang dikaji dan, 3) Pengalaman dan kesan sebagai hasil pembelajaran lebih melekat pada diri peserta didik. Hal ini karena menurut Anitah, (2014:5.25) dan Sunarti, dkk. (2016: 47-64), bahwa menggunakan metode demonstrasi memiliki keunggulan sebagai berikut: 1) Perhatian peserta didik dapat dipusatkan pada hal-hal yang dianggap penting oleh guru sehingga yang penting itu dapat diamati secara teliti, 2) Peserta didik dapat memehami bahan pelajaran sesuai dengan objek yang sebenarnya, 3) Dapat mengembangkan rasa ingin tahu peserta didik, 4) Dapat melakukan pekerjaan berdasarkan proses yang sistimatis, 5) Ekonomis dalam jam pelajaran di sekolah dan ekonomi dalam waktu yang panjang dapat diperlihatkan melalui demonstrasi dengan waktu yang pendek, 6) Dapat mengurangi kesalahan- 
kesalahan bila dibandingkan dengan hanya membaca dan menyimak, dan 7) Problem yang membuat pertanyaan dapat diperjelas waktu proses demonstrasi. Hasil pada siklus 2 yang mendapatkan ketuntasan secara maksimal $100 \%$ hal ini disebabkan bahwa metode ini memiliki kelamahan yaitu 1) Sering terjadi peserta didik kurang berani dalam mencoba atau hanya dapat menimbulkan cara berfikir yang kongkrit saja, 2) Jika jumlah peserta didik banyak dan posisi peserta didik tidak diatur maka demonstrasi tidak efektif, 3) Bergantung pada alat bantu yang sebenarnya, 4) melakukan praktik yang didemonstrasikan, dan 5) Tidak semua hal dapat didemonstrasikan di kelas

Demikian pula penggunaan media audio visual yang dapat menaikan nilai peserta didik ini sesuaikan dengan yang disampaikan oleh Arsyad (2014), Demikia pula penelitian Sediasih (2017), dan Yuliana, et al (2015), yang bahwa dengan media dapat memberikan sebagai berikut:

1) Pembelajaran lebih menarik perhatian peserta didik sehingga dapat menumbuhkan motivasi belajar; 2) Pembelajaran menjadi lebih jelas dan bermakna, sehingga dapat dipahami oleh peserta didik, 3) Peserta didik dalam kegiatan belajar, tidak hanya menyimak uraian guru saja, tetapi juga

aktivitaslainsepertimengamati,

melakukan, memerankan, dan mendemonstrasikan, dan 4) Model atau metode megajar akan lebih bervariasi, tidak hanya komunikasi verbal atau ceramah saja oleh guru, sehingga peserta didik tidak merasa jenuh, bosan, dan guru tidak kehabisan tenaga.

Penggunaan metode demostrasi dengan menggunakan media audio visual dapat tercapainya tujuan pembelajaran IPS seperti yang disampaikan Sardjiyo, (2014:1.29) agar peserta didik memiliki kemampuan sebagai berikut: 1) Memiiki komitmen dan kesadaran terhadap nilainilai sosial dan kemanusiaan, 2) Memahami dan mengenal konsep-konsep dasar yang berkaitan dengan kehidupan masyarakat dan lingkungan, 3) Peserta didik memiliki kemampuan untuk berpikir kritis dan logis, memecahkan masalah, inkuiri, keterampilan dalam bersosialisasi, dan rasa ingin tahu, dan, 4) Peserta didik memiliki kemampuan berkomunikasi, bekerja sama, dan berkompetensi dalam masyarakat yang majemuk, ditingkat lokal, nasional, regional dan global.

Hasil penelitian ini sesuai dengan PTK seperti yang disampaikan Wardani (2014: 1.5), yaitu 1) Untuk memecahkan permasalahan nyata yang terjadi di dalam kelas yang dialami langsung dalam interaksi antara guru dengan peserta didik yang sedang belajar, meningkatkan profesionalisme guru, dan menumbuhkan budaya akademi di kalangan para guru. Mutu pembelajaran dapat dilihat dari meningkatnya hasil belajar peserta didik , baik yang bersifat akademi yang tertuang dalam nilai ulangan harian (formatif), ulangan tengah semester (sub-sumatif) dan ulangan akhir semester (sumatif) maupun yang bersifat nonakademis, seperti motivasi, perhatian, aktivitas, minat, dan lain sebaginya. 2) Peningkatan kulitas praktik pembelajaran di kelas secara terusmenerus mengingat masyarakat berkebang secara cepat. 3) Peningkatan relevan pendidikan, hal ini dicapai melalui peningkatan proses pembelajaran. 4). Sebagai alat latihan, yang memperlengkapi guru dengan kemampua dan metode baru, untuk mempertajam kekuatan analitisis dan mempertinggi kesadaran dirinya. 5) Sebagai alat pendekatan tambahan atau inovasi terhadap sistem pembelajaran yang. 6) Untuk meningkatkan kualitas pendidikan melalui praktik perbaikan pembelajaran di kelas untuk mengembangkan berbagai jenis keterampilan dan meningkatnya motivasi

belajar peserta didik. 7) Dapat menumbuhkan budaya akademik di lingkungan sekolah, sehingga tercipta sikap proaktif dalam melakukan perbaikan mutu pembelajaran secara berkelanjutan, 8) Dapat meningkatkan sikap profesional pendidikan dan tenaga kependidikan, dan 9) Dapat meningktan efisiensi pengelolaan pendidikan, peningkatan atau perbaikan proses pembelajaran.

\section{KESIMPULAN}

Berdasarkan hasil penelitian perbaikan pembelajaran yang telah dilaksanakan 
mulai dari prasiklus, siklus 1 sampai dengan siklus 2 pada mata pelajaran IPS, maka penulis dapat menarik kesimpulan sebagai berikut: Pertama, hasil prasiklus, hasil rata-rata diperoleh hanya sebesar 65,5 dan peserta didik yang tidak mencapai KKM yaitu sebanyak 19 dari 41 peserta didik $(46,341 \%)$. Serta melalui pengamatan peserta didik yang dapat menjawab pertanyaan guru baru mencapai 46,34 \% . Pada siklus I, hasil rata-rata belajar peserta didik meningkat, yaitu 69,3 dengan persentase tingkat ketuntasan 58,53\%. Yang dapat menjawab pertanyaan guru mengalami peningkatan, yaitu $70,73 \%$ kenaikan tersebut masih di bawah KKM sehingga dilanjutkan perbaikan siklus II. Pada pembelajaran siklus II, peneliti menambahkan media pembelajarannya yaitu media audio visual. Hasil rata-rata belajar peserta didik meningkat, yaitu 87,3 dengan persentase tingkat ketuntasan 92,68 $\%$ atau sebanyak 38 peserta didik dari total peserta didik 41 . Hasil pengamatan yang dapat menjawab pertanyaan guru mengalami peningkatan yaitu 85,36\%. Kenaikan tersebut sudah mencapai hasil yang diharapkan yaitu melebihi KKM.

Kedua, penggunaan metode demonstrasi dan penggunaan media audio visual dapat meningkatkan Hasil Belajar dan motivasi Peserta didik Mata Pelajaran Ilmu Pengetahuan Alam Materi Kerangka Tubuh Manusia Terhadap Hasil Belajar Peserta Didik Kelas IV SD Negeri Pitara 2 Kecamatan Pancoranmas Kota Depok.

Berdasarkan pada kesimpulan diatas ada beberapa hal yang sebaiknya dilakukan guru dalam upaya meningkatkan hasil belajar peserta didik yaitu 1) Motivasi yang kuat sangat dibutuhkan oleh seorang peserta didik sebelum melakukan pembelajaran, 2) Suasana belajar yang aktif di dalam kelas akan memotivasi peserta didik dalam belajar, dan 3) Penggunaan metode demonstrasi serta menggunakan audio visual dapat membantu peserta didik untuk lebih cepat memahami konsep materi pelajaran. Dalam hal ini metode demonstrasi serta audio visual dapat menjadi alternatif yang digunakan guru dalam mengajarkan pembelajaran IPA.

\section{DAFTAR PUSTAKA}

Abdul, Majid. Pembelajaran Tematik Terpadu, Bandung : Remaja

Rosdakarya, 2014.

Anitah W, Sri dkk, Strategi Pembelajaran di SD, Tanggerang Selatan : Universitas Terbuka, 2014.

Arsyad, Azhar, Media Pembelajaran, Jakarta : PT RajaGrafindo Persada, 2014.

Darmawan, Anak Agung, (2017), Peningkatanaktivitas dan Hasil Belajar Siswa Dalam Pembelajaran IPS Melalui Metode Demonstrasi Pada Kelas VII Semester II di SMP Negeri I Gianyar, Jurnal Ilmiah Ilmu Sosial, 3 (1), 1-13.

Erlinda.(2017). Penerapan Metode Demonstrasi Dapat Meningkatkan Hasil Belajar Siswa Terhadap Pelajaran IPA Di Sekolah Dasar, Jurnal Ilmu Pendidikan Sosial, sains, dan Humaniora. 3 (3), 585593.

Irman, R, (2017), Peningkatan Hasil Belajar Ips Melalui Metode Demonstrasi Siswa Kelas IV SD Inpres Kampus IKIP Kota Makassar, Socioedu Journal: Pendidikan, Sosial, Humaniora. 1 (2), 1-16.

Sagala, Syaiful, Konsep dan Makna Pembelajaran, Jakarta : Alfabeta, 2011.

Saparati, Amalia, Pembelajaran IPA di SD, Jakarta : Universitas Terbuka, 2012.

Sardiyo, dkk, Strategi Pembelajaran IPS di $S D$, Jakarta : Universitas Terbuka, 2014.

Simbolon, Dedi Holden, dan Sahyar. (2015), Pengaruh Model Pembelajaran Inkuiri Terbimbing Berbasis Eksperimen Riil Dan Laboratorium Virtual Terhadap Hasil Belajar Fisika Siswa. Jurnal 
Pendidikan dan Kebudayaan, 21 (3), 299-315.

Sunarti, Mohammad Jamhari, dan Ritman Ishak Paudi, (2016), Penerapan Metode Demonstrasi Pada Mata

Pelajaran IPA Untuk Meningkatkan Hasil Belajar Siswa Kelas IV SDN Padauloyo Kecamatan Ampana Tete Kabupaten Tojo Una-Una. Jurnal Kreatif Tadulako Online. 4 (4), 47-64.

Sulfemi, Wahyu Bagja. (2015). Pengaruh Metode Pembelajaran Kontekstual dan Penggunaan Media Video Pendidikan Terhadap Hasil Belajar IPS. Edutecno. 13 (2), 1-10

Sulfemi, Wahyu Bagja. (2015). Kemampuan Pedagogik Guru. Prosiding Seminar Nasional. STKIP Muhammadiyah Bogor 1. (1).

Sulfemi, Wahyu Bagja. (2015). Challenges Of Indonesian Teacher Competence in dealing with Asean Economic Cummunity (AEC). Engglis Forum. 1 (1), 6979

Sulfemi, Wahyu Bagja. (2016). Kompetensi Profesionalisme Guru Indonesia dalam Menghadapi MEA. Prosiding Seminar Nasional STKIP Muhammadiyah Bogor. 1 (1), 62-77

Sulfemi, Wahyu Bagja. (2016). Hubungan Persepsi Peserta Didik Tentang Kompetensi Guru Mata Pelajaran Sejarah dengan Hasil Belajar Mata Pelajaran Sejarah di Kelas X SMA Negeri 1 Pamijahan Kabupaten Bogor, fascho, 5 (2). 52-70.
Sulfemi, Wahyu Bagja dan Lestari, Ayu Hopilatul. (2017). Korelasi Kompetensi Pedagogik Guru dengan Prestasi Belajar Mata Pelajaran IPS Di SMP Muhammadiyah Pamijahan Kabupaten Bogor. Edutecno. 16 (1), 1-16

Sulfemi, Wahyu Bagja dan Abdul Qodir. (2017). Hubungan Kurikulum 2013 Dengan Motivasi Belajar Peserta Didik Di SMK Pelita Ciampea. Edutecno 17 (2), 1-8

Sediasih, (2017). Meningkatkan Hasil Belajar Sisw dengan Menggunakan Model Make a Match Pada Mata Pelajaran PKN dikelas V SDN Karya Wangi 2, JPSD. 3 (1), 7481.

Salim, Nur Agus, (2018), Peran Kepemimpinan Kepala Sekolah Dalam Meningkatkan Kinerja Guru dI SDN Kecamatan Samarinda Ilir Tahun Pelajaran 2017/2018. Jurnal Pendas Mahakam. PENDAS MAHAKAM: Jurnal Pendidikan Dasar, Vol 3 (1), 46-54.

Yuliana, Rina, Cahyani, Isah, \& Sastromiharjo, Andoyo. (2015). Penerapan Strategi Partisipatif Melalui Media Gambar Denah Dan Kartu Pancing Foto Dalam Pembelajaran Pemahaman Konsep Dan Berbicara Siswa Sekolah Dasar. JPSD, 1 (2), 98-108.

Wardani, Igak, (2014). Pemantapa Kemampuan Profesional, Jakarta : Universitas Terbuka.

Widaryanto dan Sulfemi, Wahyu Bagja. (2016). Korelasi Penguasaan TIK Guru dengan Kemampuan TIK Siswa. Edutecno. 14. (1). 1-10. 